\title{
Comparative evaluation of the performance of an improved solar-biomass hybrid dryer
}

\author{
Edmund C Okoroigwe* \\ National Centre for Energy Research and Development, University of Nigeria, Nsukka, Nigeria \\ Department of Mechanical Engineering, University of Nigeria, Nsukka, Nigeria
}

Evidence C Ndu

Department of Mechanical Engineering, University of Nigeria, Nsukka, Nigeria

Florence C Okoroigwe

Natural Science Unit, School of General Studies, University of Nigeria, Nsukka, Nigeria

\begin{abstract}
A solar biomass hybrid dryer intially designed with a front pass flat plate solar air heater and a biomass heating stove was redesigned, reconstructed in order to minimize the excessive convective heat losses and its performance re-evaluated. Due to poor design and contruction of the biomass heating and solar collector sections, the efficiency of the initial design was low. It is believed that the drying efficiency of the dryer could be enhanced if a back pass solar collector and a biomass heating stove incorporated with a gas to gas heat exchanger to ensure that the hot air reaching the samples is clean, smokeless and ash free, substitute for the original solar collector and biomass unit respectively in the improved version. The system's drying performance was tested on both no load and full capacity load under different meteorological conditions within Nsukka $\left(\right.$ Lat. $\left.7^{\circ} \mathrm{N}\right)$ for two weeks. The testing results showed that the incorporation of a new back pass solar collector and the heat exchanger enhanced the trays temperatures on no load test. Similarly, the efficiency of the dryer based on solar, biomass and solarbiomass heating in drying of fresh okra, fresh groundnut and fresh cassava chips increased from $5.19-16.04 \%, 0.23-3.34 \%$ and $1.636-8.96 \%$ respectively over the initial construction. This shows that the dryer can help improve the post-harvest processing and storage quality of farm produce by drying if further optimized.
\end{abstract}

Keywords: solar, biomass hybrid dryer, drying efficiency, drying rate, post-harvest processing

\footnotetext{
* Corresponding author:

edmund.okoroigwe@unn.edu.ng, +2348057156223
}

\section{Introduction}

Post-harvest drying of farm produce is one of the main crop preservation techniques employed to enhance crop processing, storage quality, nutritional value and market control. Most fruits and vegetables in Nigeria are seasonal. It is therefore necessary to preserve them and use them during scarce periods. Removal of moisture (drying) retards many of the moisture-related deteriorative reactions and prevents the growth and reproduction of micro-organisms (Naidu et al., 2016, Fudholi et al., 2015, Dincer, Hussain, Sahin, \& Yilbas, 2002). Drying can be achieved in diverse ways depending on the cost involved. Use of solar and biomass in drying are considered cheaper and readily available to farmers in developing countries than mechanical dryers used in an industrial set up (Chavan et al., 2008, Hossain et al., 2008). In a solar energy drying application, one major limitation is the timedependent nature of solar radiation. The availability of solar energy only during sunshine hours makes it difficult to use this energy source when the sun sets without auxiliary heat backup. Auxiliary heat backups inform of an additional heat source/storage aid to reduce drying time (Khalifa et al., 2012), increase efficiency (Phadke et al., 2015), and ensure continuous drying (Bal et al., 2010). In solar energy applications, solar drying depends on the solar radiation intensity such that tropical regions stand advantaged over temperate regions. After sunset and during cloudy days, biomass heat source becomes a cheap alternative and/or supplementary source of heat for drying. Solar drying of vegetables has been reported to be the best in terms of nutrient retention compared with sun drying and oven drying (Kiremire et al., 2010). Therefore, a combination of a mixed mode drying system, using solar 
energy as main input, and a biomass burner as auxiliary source of thermal energy will compensate for the absence of the solar radiation during cloudy, rainy days and nights (Yassen and Al- Kayiem 2015).

Traditionally, in developing countries, solar drying is mostly based on open sun drying because of its low cost (Prakash and Kumar 2014, Rathore et al., 2012,). Open sun drying, even though inexpensive, produces dried products of very poor quality with contamination (Okoroigwe et al., 2013; Ratti and Mujumdar, 1997; Prasad et al., 2006). One of the ways of reducing post-harvest losses and improving the quality of products with minimal contamination in solar drying is by drying agricultural crops in closed structures known as solar dryers. Solar drying, based only on solar radiation is also subject to low quality products because such products would absorb moisture at night or during high humidity days due to dryness differential. In order to ensure continuous moisture removal until dryness is achieved in solar dryers, integration of heat storage systems or auxiliary heating devices into the solar dryer is most ideal. Such dryers with backup systems or auxiliary heating devices, such as biomass combustion chambers tend to produce better quality dry products than ordinary solar dryers without backup systems. Many researchers have studied solar dryers incorporated with auxiliary heaters or thermal energy storage systems which are reported in the literature (Barki et al., 2012; Ibrahim et al., 2014; Madhlopa and Ngwalo, 2007; Smitabhindu et al., 2008; Fudholi et al., 2010). For instance, it has been shown that dryers operated on conventional energy sources such as gas, kerosene, electricity and coal are more efficient but are beyond the reach of rural people with limited farm products (Yunus et al., 2011, Prasad et al., 2006) and income. Biomass based dryers could be cheaper and more affordable where income level and farm size are issues even though they can be applied in large scale commercial processing units. In such cases, farm residues (biomass) can be utilized to provide additional energy in farm crop processing thereby increasing the value addition of the farmers' agricultural business. Research and development activities in solar drying are geared towards developing more efficient solar dryers with backup auxiliary biomass heating (Hashemi et al., 2003; Hossain, 2008; Leon and Kumar, 2008; Lokeswaran and Eswaramoorthy 2013; Agrawal and Sarviya 2014).

The performance of mixed mode dryers depends on the design and selection of all sources of heat inputs. The initial design prototype work (Okoroigwe et al., 2013) a front pass flat plate solar air heater featured as the primary absorber of solar energy for the drying process was used while a charcoal stove was the auxiliary heater. Due to the excessive convective heat losses associated with front pass solar collectors and the poor design of the biomass combustion unit, the efficiency of the dryer was only about $5.19,0.23$ and $1.64 \%$ on solar, biomass and solar-biomass heating respectively. It is thus believed that the drying efficiency of the dryer could be enhanced if a back pass flat plate solar collector substitutes the original design in the improved version. A back pass solar collector has two air columns. The first is the stagnant air column between the glass cover and the absorber plate that forms an insulating layer to reduce the convective heat loss through the glass cover. The second air column is the open air channel between the underside of the absorber plate and the top side of the back plate.

This type of collector is suitable for solar drying applications since moderate temperature is required for food and agricultural crop drying. This is because the action of applying heat to farm produce in order to dry it does not merely remove the moisture but can also affect the nutritional qualities of the dried product (Onayemi, 1981). For instance, the ideal temperature range for drying a vegetable is between 35 and 60 since most enzymes are destroyed at higher temperatures of above 60 (Kordylas, 1990). In addition, beta-carotene (precursor of Vitamin A) is lost at temperatures above $100^{\circ} \mathrm{C}$ while vitamin $\mathrm{C}$, a thermolabile vitamin, is also lost by long drying time and high temperature. This suggests why precaution should be taken while drying food crops.

The biomass burner was a commercial charcoal stove that had a fixed perforated grate to allow ash drop into the lower ash tray. Its wall was aligned with clay as refractory material to reduce heat loss by conduction and was connected to a conical top aligned with clay which directs hot gases to a pipe. The pipe conveys the flue gas to the drying trays in the drying chamber. The major setback of this prototype design (Okoroigwe et al., 2013) was the direct exposure of the crops/food to the hot flue gases that generally contain smoke, ash, solid particles and other contaminants from the biomass combustion chamber. In addition, excessive convective heat losses were experienced. Since the biomass burner was based on adapting an already existing charcoal stove for domestic cooking, there was a need to redesign the biomass heating chamber (unit) to suit the demand of the solar hybrid dryer. This was done by incorporating a suitable gas to gas heat exchanger to ensure that the hot air reaching the samples is clean, smokeless and ash free. By incorporating this in the improved design, the hot flue gases flow inside a duct and then exchange heat with the drying air in contact with the surface of the heat exchanger. This process produces heated clean air for the drying process in the drying chamber. In addition, the heat exchanger minimizes 
thermal losses by convection and losses through vents and openings on the dryer walls.

In the present study the performance of the improved version of the solar-biomass hybrid dryer is evaluated in terms of temperature distribution in the trays in both no load and load conditions, moisture reduction in samples and drying efficiencies. The efficiency of the dryer is evaluated under solar drying only, biomass heating only and combined biomass and solar heating conditions.

\section{Materials and methods}

The schematic diagram of the dryer is shown in Figure 1 showing the 3-D view of the interior and the exterior components respectively. The dryer comprises a drying chamber- 1 , the back pass flat plate solar collector-2, biomass heating chamber-3, drying tray racks- 4 , heat exchanger- 5 and chimney6 for moisture exit. There are three drying trays numbered $1-3$ starting from bottom of the drying chamber to the top. The dryer body is made of an Aluminum frame while the drying chamber (transparent body) is made of Perspex glass for direct incident solar radiation on the drying samples. Table 1 shows the summary of some parameters of the improved dryer.

Since there is no standard method of evaluating solar dryers (Bena and Fuller 2002; Madhlopa and Ngwalo 2007) the performance of the improved hybrid dryer was evaluated under load and no load test conditions. The no load tests were aimed at

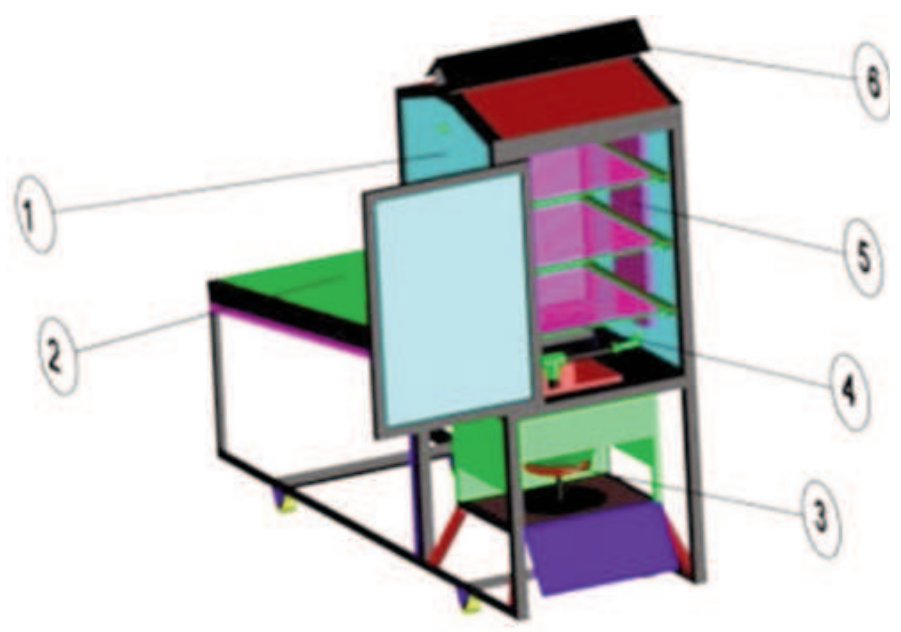

Figure 1: Schematic diagram of the improved dryer system

determining the temperature distribution in the drying chamber at the different tray levels for solar only from 9.00 am to $6.00 \mathrm{pm}$ on the test date and biomass heating from and $9.00 \mathrm{pm}$ to $1.00 \mathrm{am}$. For the biomass heating, $0.7 \mathrm{~kg}$ of wood charcoal was used but after 2 hours, $0.3 \mathrm{~kg}$ was added. The solar input to the system was based on estimation of total hourly average solar radiation on the tilted collector surface and transparent wall (drying chamber). The detailed solar radiation estimate using standard models and procedure are outside the scope of this work. The hourly solar radiation data on the hori-

Table 1: Summary of some parameters of the dryer

\begin{tabular}{|c|c|c|c|}
\hline \multirow[t]{2}{*}{ Section } & \multirow[t]{2}{*}{ Description } & \multicolumn{2}{|c|}{ Value } \\
\hline & & Old design & Improved \\
\hline \multirow[t]{7}{*}{ Solar collector } & Length (m) & 0.64 & 1.2 \\
\hline & Width $(\mathrm{m})$ & 0.61 & 0.61 \\
\hline & Air space $(\mathrm{m})$ & 0.03 & 0.03 \\
\hline & Wetted area $\left(\mathrm{m}^{2}\right)$ & 0.0183 & 0.0183 \\
\hline & Tilt angle, $\beta$ (degrees) & 7 & 7 \\
\hline & Average exit temperature $\left({ }^{\circ} \mathrm{C}\right)$ & & 38.02 \\
\hline & Average efficiency (\%) & & 61.42 \\
\hline \multicolumn{4}{|c|}{ Insulating material } \\
\hline \multicolumn{4}{|l|}{ Saw dust } \\
\hline & Thermal conductivity $\left(\mathrm{W} / \mathrm{m}^{2} \mathrm{~K}\right)$ & - & 0.059 \\
\hline \multicolumn{4}{|l|}{ Biomass section } \\
\hline & Biomass stove \& fuel type & $\begin{array}{c}\text { Toyola cook stove } \\
\text { /charcoal }\end{array}$ & $\begin{array}{c}\text { Toyola cook stove } \\
\text { /charcoal }\end{array}$ \\
\hline & Biomass stove efficiency (\%) & 60 & 60 \\
\hline & Heat exchanger & - & yes \\
\hline & Heating chamber $(\mathrm{m})$ & $0.3 \times 0.3 \times 0.3$ & $0.3 \times 0.3 \times 0.3$ \\
\hline & Heat exchanger material/cross sectional area $\left(\mathrm{m}^{2}\right)$ & - & Aluminum/ 0.005 \\
\hline & Maximum allowable drying temperature $\left({ }^{\circ} \mathrm{C}\right)$ & 70 & 70 \\
\hline & Average latent heat of evaporation of water $(\mathrm{KJ} / \mathrm{kg})$ & 2257 & 2257 \\
\hline
\end{tabular}


zontal surface on the test dates was obtained from the Centre for Basic Space Science (CBSS), Nsukka Nigeria.

Even though Madhlopa and Ngwalo (2007) and Leon et al. (2002) recommended first and last day efficiencies for evaluation of solar dryer drying efficiencies, those of the solar collector and the improved hybrid dryer were based on the total energy input over the duration of the test. The flat plate solar collector efficiency was estimated using equation 1.

$$
\eta=\frac{Q_{u}}{A_{c} H_{t}}=\frac{m_{a} c_{p a}\left(T_{e}-T_{i}\right)}{A_{c} H_{t}}
$$

where the numerator is the useful heat gain and the denominator is the solar heat input to the system, $\mathrm{T}_{e}$ and $\mathrm{T}_{\mathrm{i}}$ are collector exit and inlet temperatures respectively and $\mathrm{m}_{\mathrm{a}}$ is mass flow rate of air (product of air density, wind speed and the air duct area), Cpa is the specific heat capacity of air at constant pressure

The performance of the dryer was carried out using three different crops on different modes of operation for the load performance tests. Fresh okra (Abelmoschus esculentus), shelled fresh groundnut (Arachis hypogea) and fresh cassava chips (Manihot esculenta) were used for solar, biomass and solarbiomass drying respectively. The solar drying of okra vegetable was for two days using sliced samples measuring $20 \mathrm{~mm}$ in diameter by $7 \mathrm{~mm}$ thickness. The biomass drying test alone of peanut (groundnut) lasted for seven hours using $1.2 \mathrm{~kg}$ of wood charcoal. The test period was from $1.00 \mathrm{am}$ to 8.00 am on the test day to ensure that the solar component was excluded from this test. The solarbiomass hybrid test was based on drying of cassava chips measuring $5 \mathrm{~mm}$ thick by $40 \mathrm{~mm}$ in diameter. About $1.4 \mathrm{~kg}$ of wood charcoal as fuel was used together with solar radiation through the collector and the glass cover of the drying chamber.

The drying samples for the load test were washed and properly sliced before feeding them into the drying chamber. Weight loss of the samples on each tray was measured and recorded at regular intervals of one or two hours as applicable. The initial moisture content of the samples was determined using Ohaus Moisture Analyser model MB 23 Halogen before loading them into the dryer. The moisture analyser operates on the thermos-gravimetric principle. At the commencement of the test, the moisture analyser determined the mass of the sample, after which it was quickly heated at a preset temperature of $105^{\circ} \mathrm{C}$ by a halogen lamp. Subsequent moisture contents were calculated based on the weight losses recorded at regular time intervals using equation 2 .

$$
m_{c}(\%)=\frac{\left(M_{i}-M_{d}\right)}{M_{i}} \times 100
$$

Where $M_{i}$ is the initial mass of the sample $(\mathrm{g})$ and $\mathrm{M}_{\mathrm{d}}$ is the mass of dry matter in the sample obtained using the initial moisture content from the analyser by $\left(1-m_{c}\right) \times M$. M is the initial sample mass while $\mathrm{m}_{\mathrm{c}}$ is the moisture content value from the analyser. For instance, the initial moisture content of the Okra was $27.3 \%$ (obtained using the analyser). Each tray was loaded with $670 \mathrm{~g}$ of sample. It implies that the dry matter in the tray was $(1-0.273) \times 670=$ $487.09 \mathrm{~g}$.

The drying rate of the ith time was estimated from:

$$
\mathrm{d}_{\mathrm{r}(i t h)}=\frac{\left(\mathrm{m}_{\mathrm{i}}-\mathrm{m}_{\mathrm{f}}\right) \text { ith }}{\mathrm{t}(\mathrm{ith})}
$$

where $m_{i}$ and $m_{f}$ are the initial and final masses respectively of the ith time and $t$ is the time interval. The average drying rate is computed from the total moisture loss over the total time taken to dry.

The efficiency of the solar-biomass dryer was evaluated based on the mode of its operation. Thus when solar radiation was used as the only source of energy, the efficiency was calculated as shown in equation (4):

$$
\eta_{d}=\frac{M_{w} L_{v}}{\eta_{c} A_{c} H_{t}+Q}
$$

$\mathrm{Q}$ is the solar heat gained through the wall and the roof of the drying chamber,

$\eta_{\mathrm{c}}$ is average solar collector efficiency,

$\mathrm{A}_{\mathrm{c}}$ is area of solar collector

$\mathrm{H}_{\mathrm{c}}$ is total solar radiation energy on the collector

$\mathrm{M}_{\mathrm{w}}$ is mass of water removed,

$\mathrm{L}_{\mathrm{v}}$ is latent heat of vaporization of water.

When the biomass is the only source of energy, the efficiency becomes

$$
\eta_{d}=\frac{M_{w} L_{v}}{\eta_{s, b} m_{f} H_{f}}
$$

$\mathrm{H}_{\mathrm{f}}$ is the heating value of the fuel (charcoal), is the mass of charcoal burnt and is the biomass stove combustion efficiency. Similarly, when the dryer is operated on both solar and biomass heating, the efficiency of the dryer is estimated - thus:

$$
\eta_{d}=\frac{M_{w} L_{v}}{\left(\eta_{c} A_{c} H_{t}+Q\right)+\eta_{S, b} m_{f} H_{f}}
$$

The terms are as earlier defined.

\section{Results and discussion 3.1 Temperature distribution on no load} tests

Figures 2 and 3 show the temperature distribution in the trays on solar and biomass heating respectively. The temperature in the trays was affected by 
the total thermal energy from the solar collector and thermal energy received directly from solar radiation through the walls.

There was direct correlation between the solar radiation energy received and the temperature during the early and late hours of the test day. The sudden temperature drop at $12.22 \mathrm{pm}$ (solar time) in the trays even though the solar radiation was high, could be attributed to sudden increase in the wind speed The wind speed is responsible for convective heat transfer between the collector and the drying chamber since the working fluid is air. The energy output of the dryer on no load test in solar heating only was based on the mass flow rate of the working fluid which is a function of the air density and wind speed. Sudden increase in wind speed reduced the air residence time in the collector air duct thereby reducing its energy content as it flows into the drying chamber. The uniform distribution of temperature in the trays in Figure 2 shows that both the solar collector and the transparent walls contributed very well to the heating of the trays meaning that uniform drying could be obtained in the samples irrespective of their position in the chamber. The maximum temperature attained was $49^{\circ} \mathrm{C}$, which was higher than $44^{\circ} \mathrm{C}$ achieved using the initial design (Okoroigwe et al., 2013) even though the latter was taken around 3pm as against 11.22am (solar time) in this work. The maximum temperature attained for biomass heating (Figure 3) was around $67^{\circ} \mathrm{C}$, at the outset of the experiment, in tray 1 , which was closest to the heat source.

\subsection{Solar collector efficiency}

The hourly solar collector efficiency variation of the new solar collector is presented in Figure 4 showing

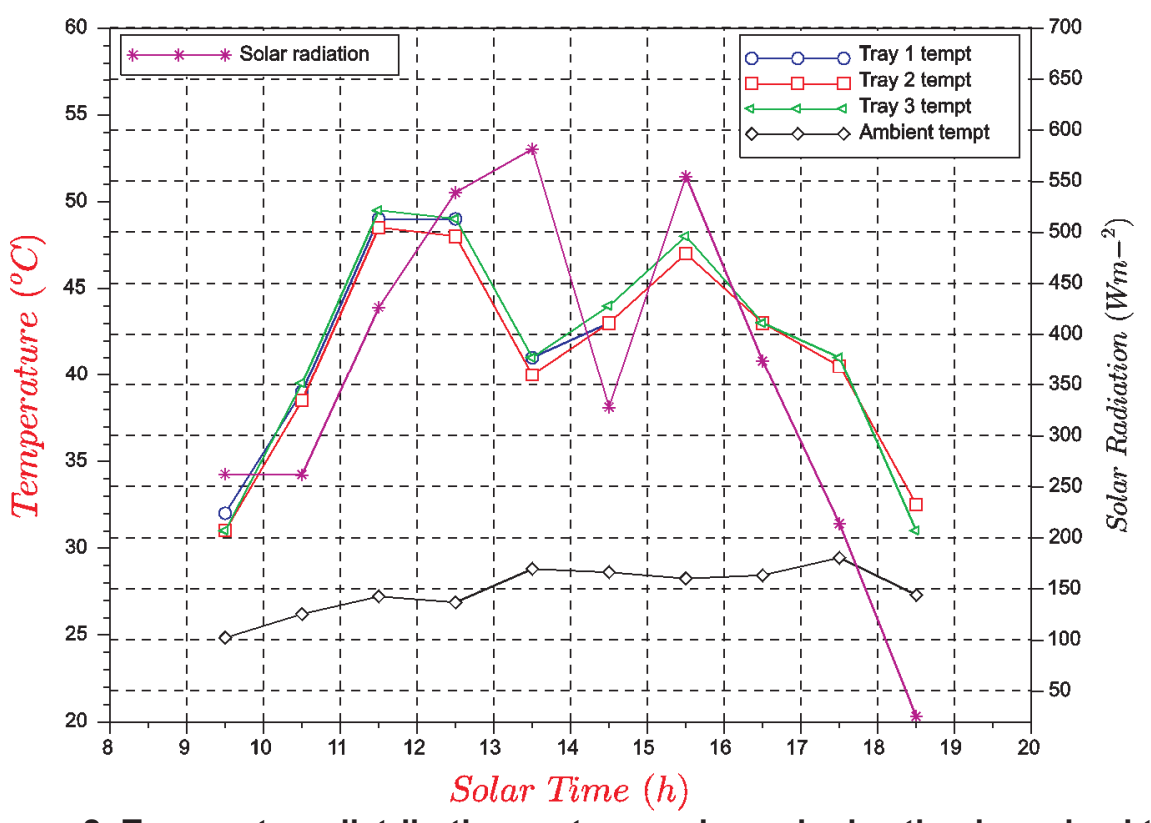

Figure 2: Temperature distribution on trays using solar heating in no load test

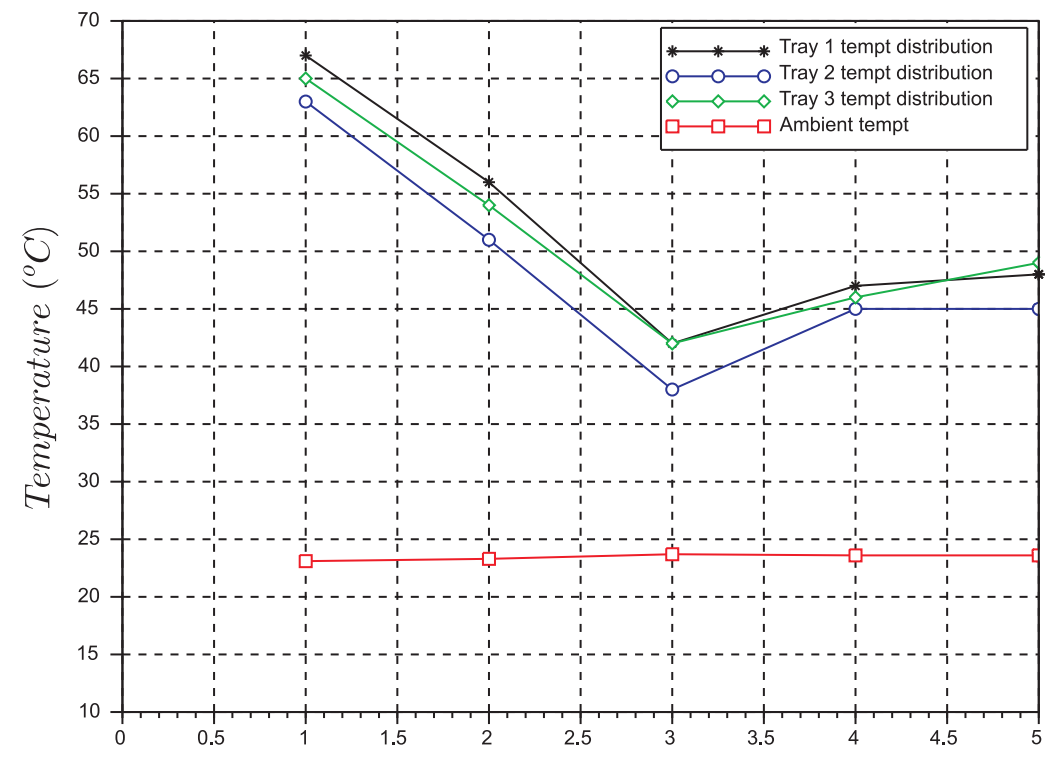

Figure 3: Temperature distribution in trays using biomass heating in no load test 


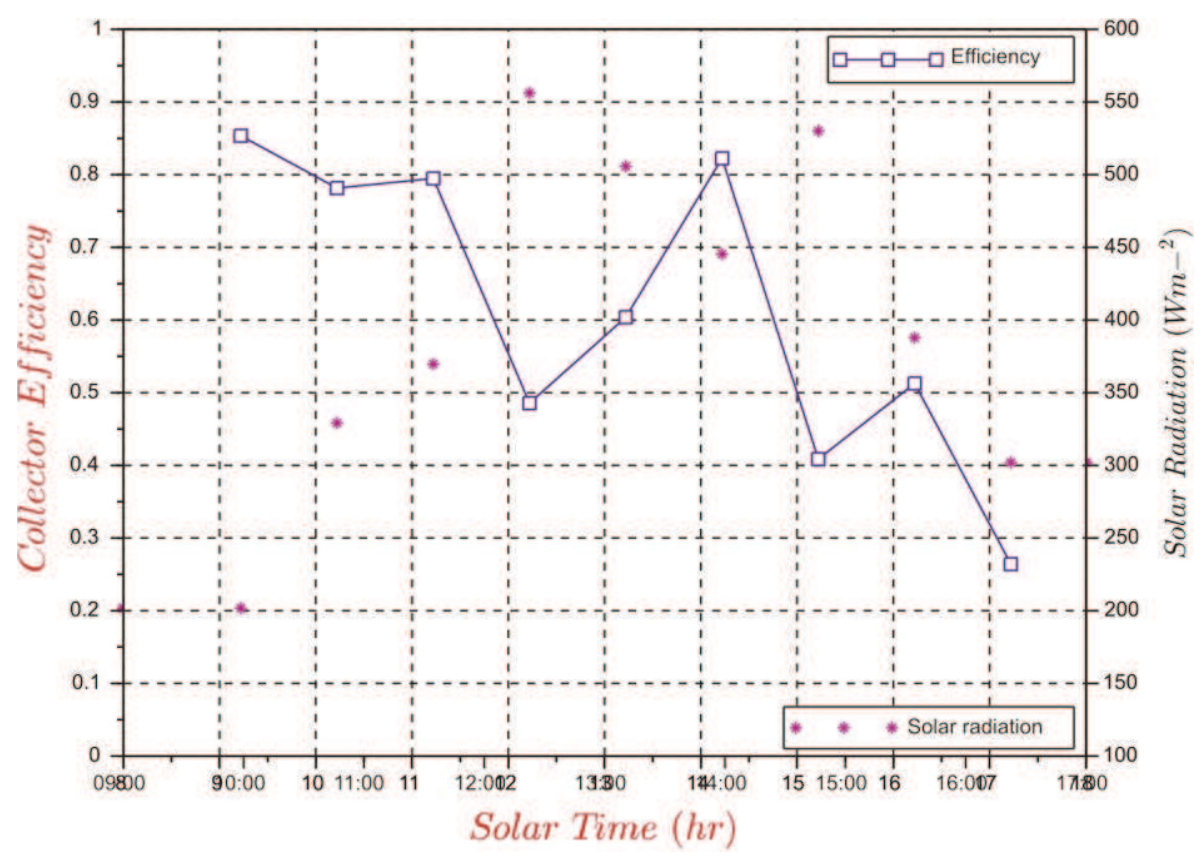

Figure 4: Solar collector efficiency variation with time and solar radiation intensity

that the efficiency varied from 0.2641 at about $17.22 \mathrm{pm}$ (solar time) to about 0.8536 at $9.22 \mathrm{am}$. The average solar collector efficiency is calculated as $0.6142(61.42 \%)$. At the beginning of the experiment, solar energy was low and the temperature was relatively high (Figure 2), hence the high efficiency. The wind speed is a function of the mass flow rate of air in the duct which affects the efficiency (Dovic and Andrassy 2012). Another reason for variation of collector efficiency with solar radiation is heat loss through the edges of the solar collector due to constructional deficiencies. Temperature variation between the collector plate temperature and the ambient air contributed to heat losses to the environment, hence changes in the values of efficiency estimated.

\subsection{Solar drying of okra vegetable}

a) Moisture content

Parameters obtained for drying okra vegetable using solar radiation are presented in Figures 5-7, where Figures $5 \mathrm{a}$ and $5 \mathrm{~b}$ present moisture variation in the first and second day respectively. The initial moisture content of the fresh okra was $81 \%$ on a wet basis. On the first day (Figure 5a) the moisture content continued to decrease uniformly in the trays at an average rate of $1.4 \% / \mathrm{hr}$. This confirms uniform temperature distribution in the trays during the solar heating test on no load test (Figure 2) and agrees with the trays temperature distribution profiles on solar drying of the crop on first day (Figure $7 a)$.

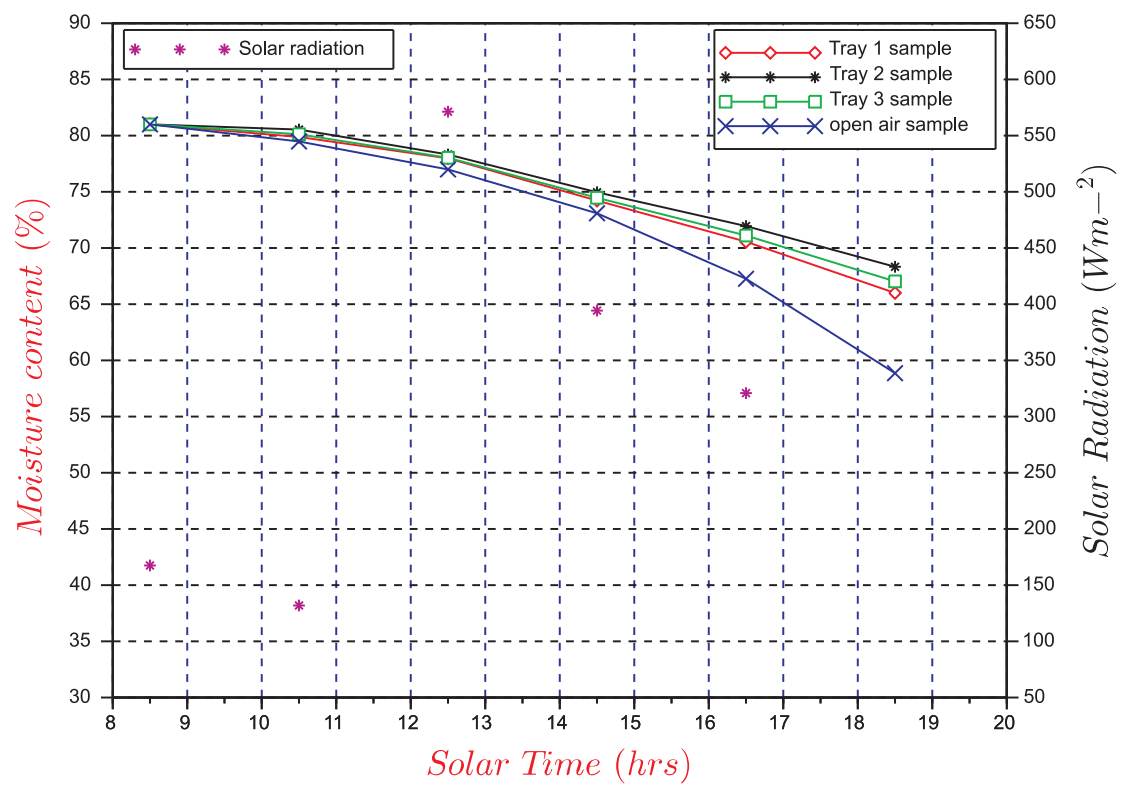

Figure 5a: Moisture content of the okra on first day 


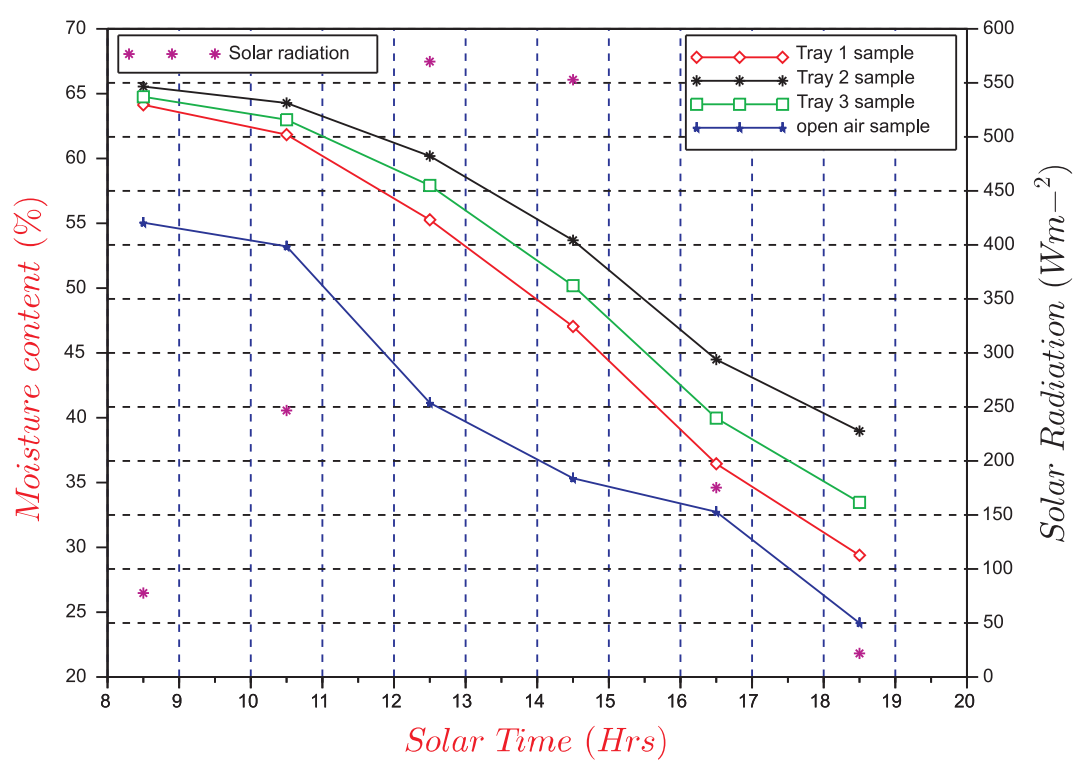

Figure 5b: Moisture content of the okra on the second day

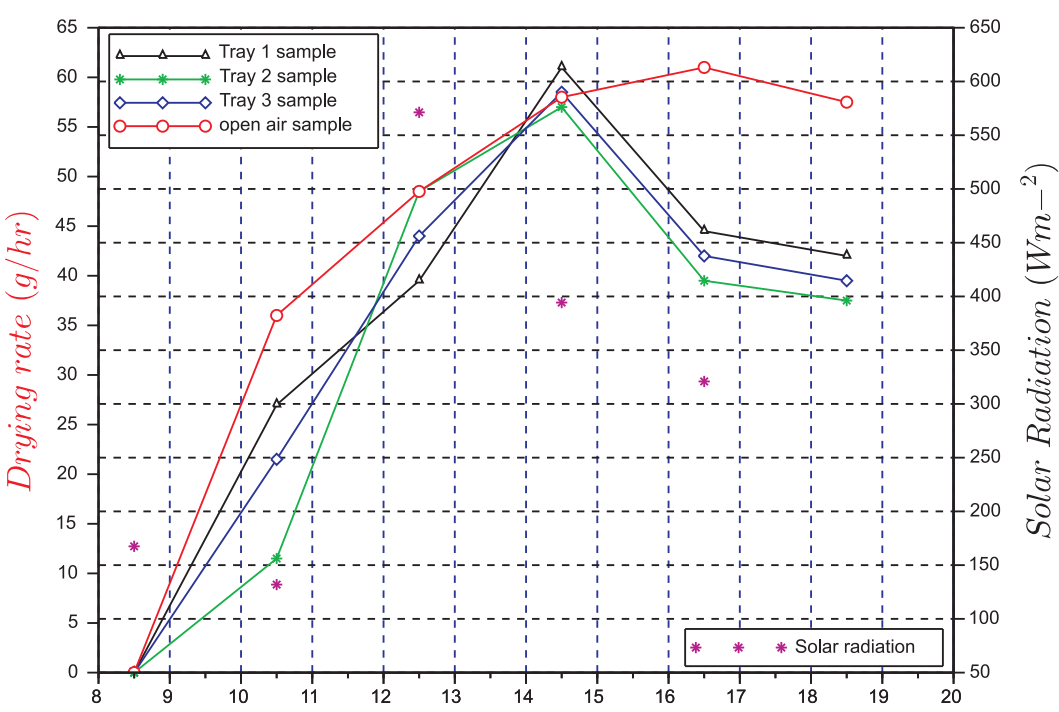

Figure 6a: Drying rate of the okra on the first day

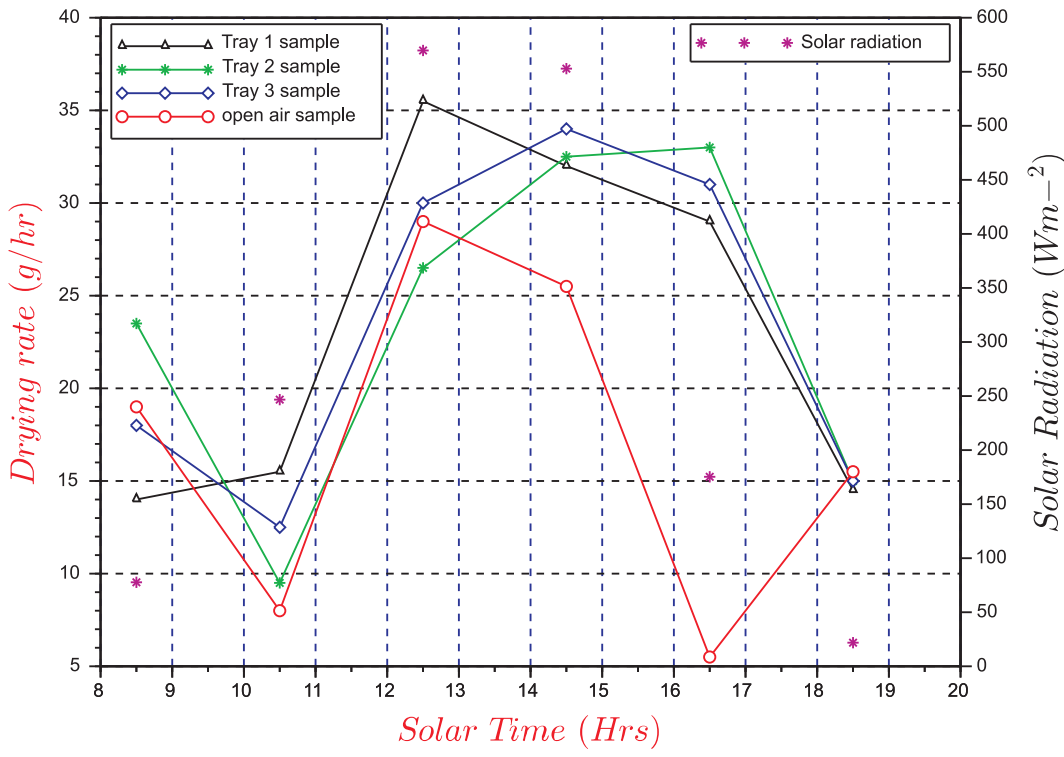

Figure 6b: Drying rate of the okra on the second day 
The moisture content on an open air tray began to decrease more than those of the trays in the dryer at $13.22 \mathrm{pm}$ (solar time) because of sudden increase in wind speed to about $1.13 \mathrm{~m} / \mathrm{s}$ and continued to decrease to $58 \%$ at the end of experiment. Environmental factors such as wind, surface area, humidity and ambient temperature favoured open air drying more than those in the dryer. The average sample moisture content dropped from $81 \%$ to $67.12 \%$ on the first day and to $33.94 \%$ on the second day. During the second day drying, moisture content variation (Figure $5 \mathrm{~b}$ ) showed a wider gap in the values obtained in the trays and that of open air. During this time, the hygroscopic moisture in the sample was being removed. This requires higher energy input to break the hygroscopic bond between the molecules of water and the material (tissue) of the okra. The open air tray received more radiant energy because the tray was horizontal and of a larger surface area. Loss of more moisture in open air drying has been reported by Ajao and Adedeji (2008) in the drying of okra vegetable. This differs from the result by Prasad et al. (2006), in which drying in the hybrid dryer was faster than in open air. With high relative humidity, drying in the cabinet dryer becomes more advantageous. Similarly, moisture content of mackerel was reduced from $72.50 \pm 0.44 \%$ to $16.67 \pm 0.52 \%$ and $16.92 \pm$ $0.54 \%$ in the solar biomass hybrid cabinet dryer and open sun drying respectively (Chavan et al., 2008). In the tropics, it is much cheaper and faster to dry with open air sun drying than enclosed drying, except when high temperature drying is needed. The advantage of drying in an enclosed system cannot be overemphasized, especially when the drying of medicinal plants are considered (Bala et al., 2010).

\section{b) Drying rate}

Figures $6 \mathrm{a}$ and $6 \mathrm{~b}$ show rate of moisture loss in the two day drying. Drying rate increased as solar radiation intensity increased in both days with maximum rate occurring in afternoon time. On the first day (Figure 6a) the open air drying rate was highest but decreased during the second day (Figure 6b). Even though more moisture was lost on open air drying, on the second day, Figure $6 \mathrm{~b}$ shows that the rate of drying was higher inside the dryer than in the open air with tray 1 losing more moisture per unit time than the rest of the trays. The increase in drying rate could be attributed to the slice nature of the samples as has been shown by (Prasad et al., 2006; Bala et al., 2010).

\section{c) Temperature distribution in trays}

The tray temperatures followed a trend with rise in solar radiation as the temperatures were highest at peak of solar radiation (Figures $7 \mathrm{a}$ and $7 \mathrm{~b}$ ). The collector and transparent body assisted in raising the temperature of the dryer chamber more than that of ambient air explaining the reasons for rapid and faster drying rate in the dryer trays especially on the second day (Figure 7b).

\subsection{Biomass drying of groundnut}

\section{a) Moisture content}

Figures $8 \mathrm{a}$ shows the moisture content variation as heating progressed with biomass heating. Tray 1 received much thermal energy from the biomass stove as it is closest to the source of heat. In the first 1 hour of drying, the drying rate was very high and the moisture content dropped from $27.3 \%$ to an average of $1.93 \%$ in the trays. Trays 2 and 3 were heated uniformly due to the effect of the heat exchanger hence the moisture content of the sam-

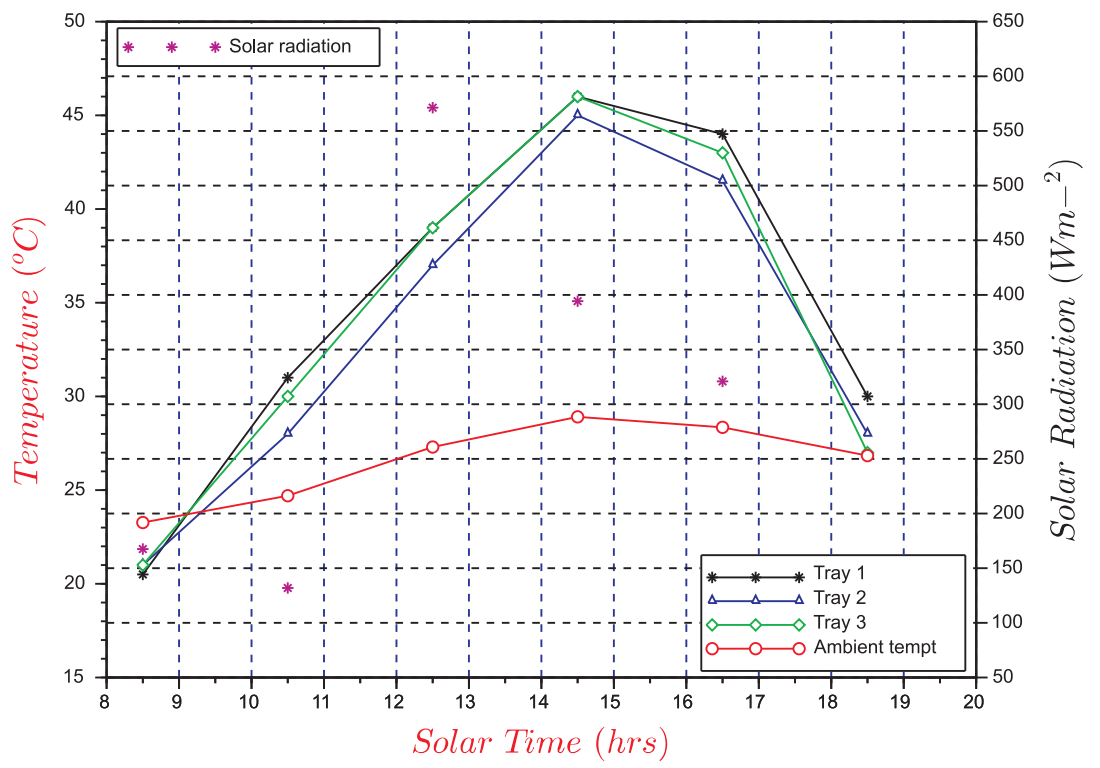

Figure 7a: Temperature distribution in trays on the first day of solar drying of okra 


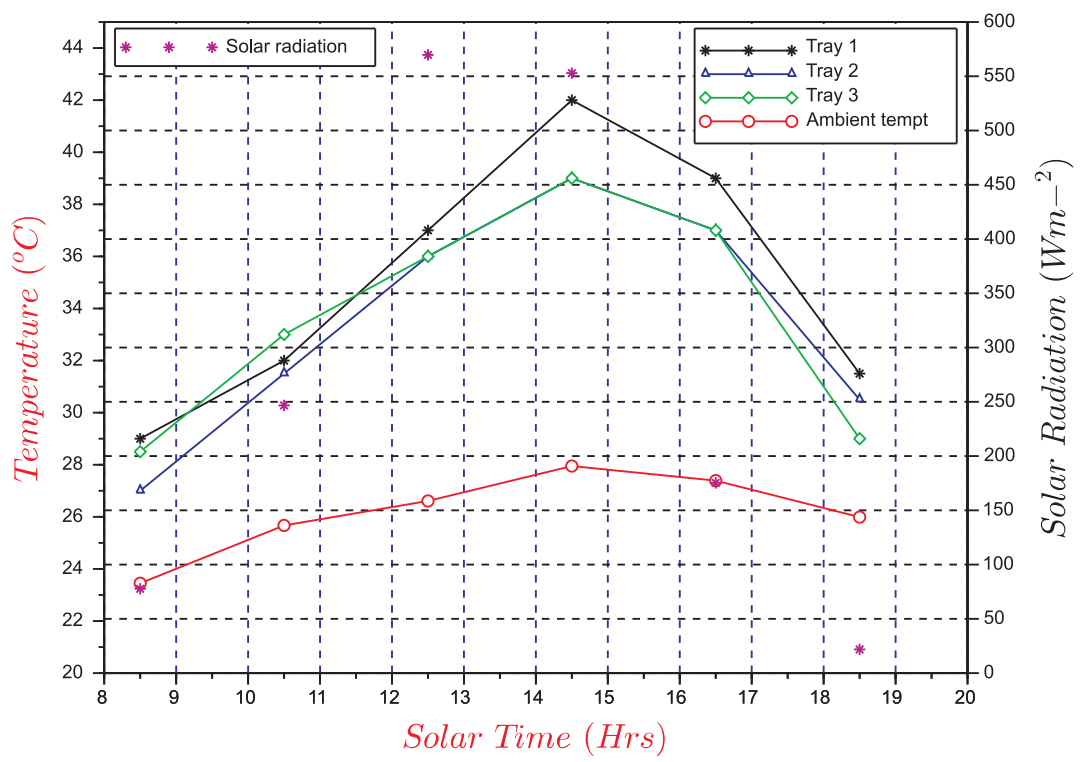

Figure 7b: Temperature distribution in trays on the second day of solar drying

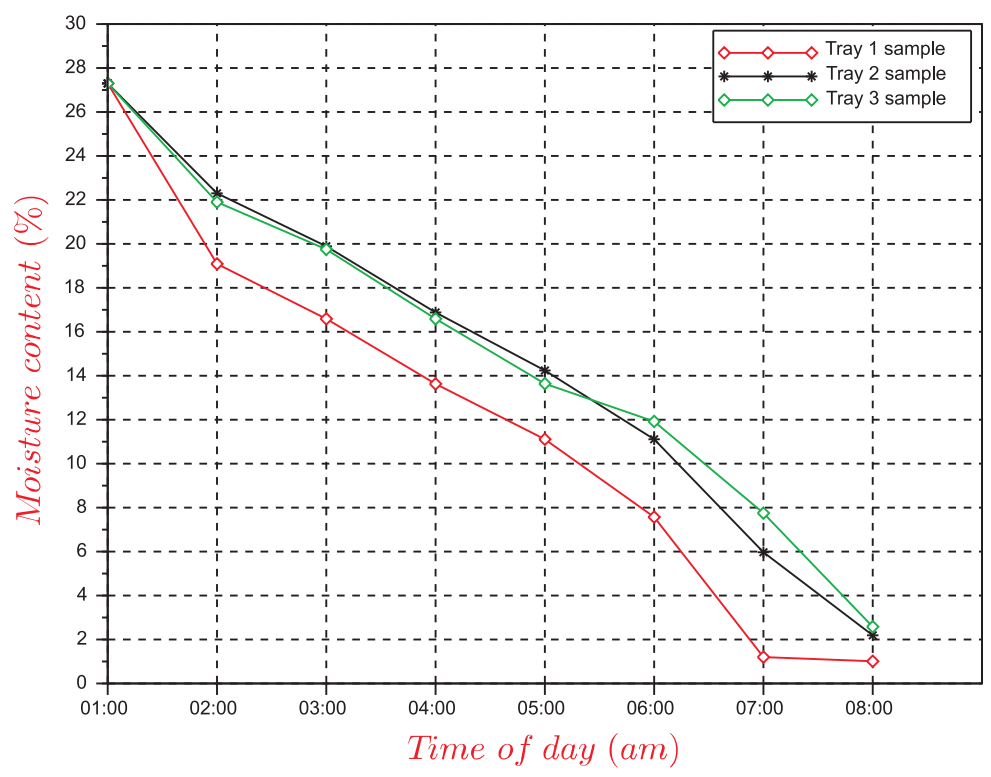

Figure 8a: Moisture content of groundnut using biomass heating

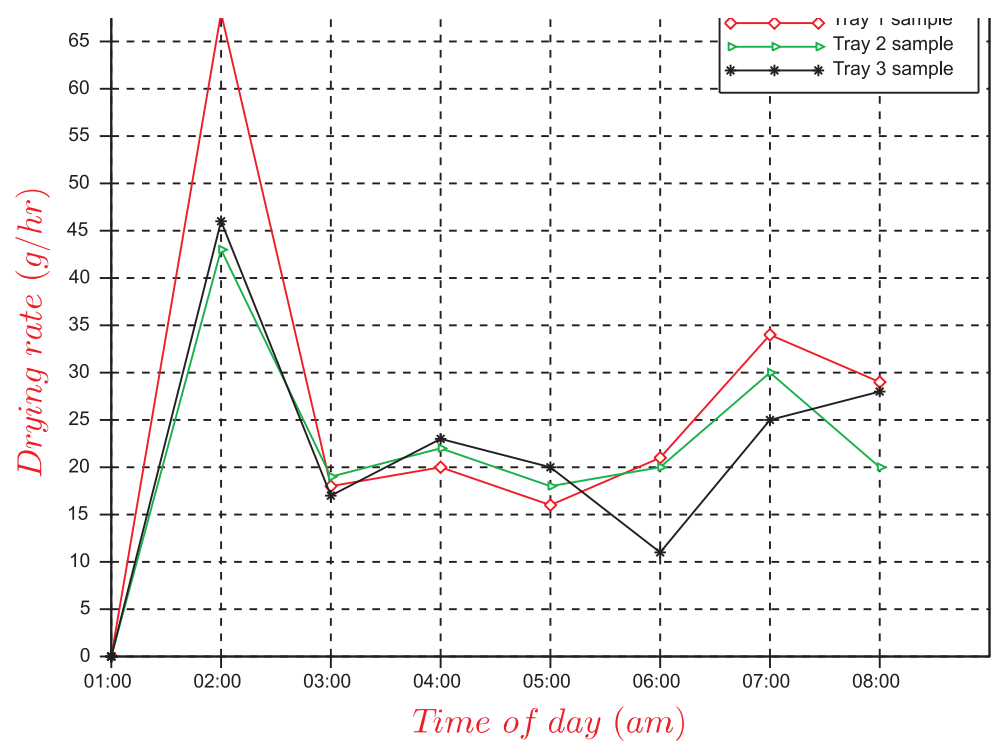

Figure 8b: drying rate of groundnut using biomass heating 
ples were almost the same. Incorporation of the heat exchanger is useful in this work for two main purposes. Firstly it assists in thermal energy distribution among the trays and secondly it conveys the flue gas away from the samples such that the drying is done without contamination from particulate matter and carbon in the flue gas.

\section{b) Drying rate}

Figure $8 \mathrm{~b}$ shows the drying rate in the trays as heating progressed showing the drying rate pattern that followed the same trend in all the trays. When heat supply by the biomass decreased, the drying rate also decreased in tray 3 due to its furthermost position with respect to the heat source.

c) Temperature distribution

Figure $8 \mathrm{c}$ shows the temperature distribution profile in the trays as biomass heating took place in the drying of peanuts. The tray 1 temperature as expected was highest due to its location with respect to the heat source. The maximum tray temperature was $53^{\circ} \mathrm{C}$ despite a low ambient temperature (20 $\left.22.2^{\circ} \mathrm{C}\right)$ and high relative humidity $(90-92 \%)$.

\subsection{Solar-biomass drying of cassava chips}

a) Moisture content

The moisture content variation in the trays for solarbiomass- heating is presented in Figure 9a showing that moisture content decreased more rapidly in tray 1 as time progressed than in other trays. There was not much variation in moisture content of trays 2 and 3 because of the combined effect of both solar and biomass heat sources. Like any other solar hybrid system, the auxiliary thermal energy supply serves to cushion the effect of low solar insolation at off periods such as nights and cloudy conditions. Here biomass heat supply appears to supply more thermal energy because of low efficiency of the solar collector and low solar insolation

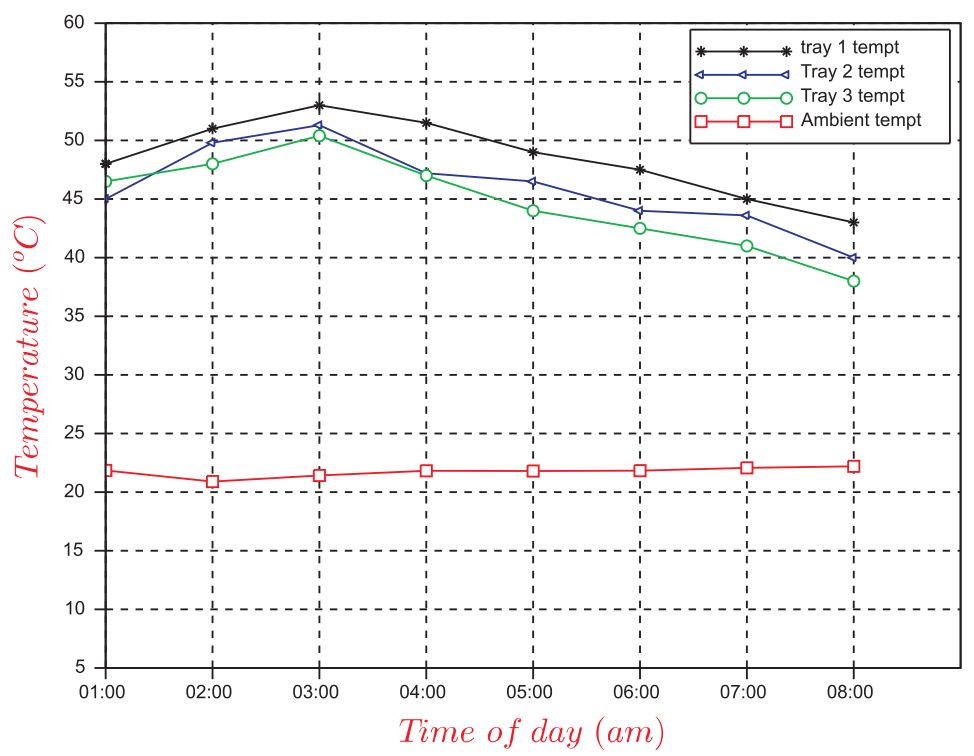

Figure 8c: Temperature distribution on trays during groundnut drying using biomass heating



Figure 9a: Moisture content of cassava chips using solar-biomass heating 
between the hours of $12.50 \mathrm{pm}$ and $16.50 \mathrm{pm}$. The moisture content dropped from $51.7 \%$ to an average of $24.1 \%$ in 5 hours despite low solar radiation.

\section{b) Drying rate}

The drying rate patterns are presented in Figure $9 \mathrm{~b}$ with tray 1 samples losing moisture more rapidly, than the rest of the trays because it is closest to the biomass heat source. The drying rate in all the trays was high in the first 2 hours of drying because of easy removal of superficial moisture than inherent moisture in the samples. This helps to prevent quick deterioration that would have occurred if the moisture remains attached to the surface of the samples. The reduction in solar radiation energy from $13.53 \mathrm{pm}$ could be responsible for the slower drying rate experienced in the trays. However, as the solar energy increased in the last hour, the drying rate in tray 3 surpassed that of tray 2 because of its exposure to more solar radiant energy than tray 2 .

c) Temperature distribution

The temperature profile in the drying chamber during solar-biomass drying is in Figure 9c with tray 1 experiencing higher temperature values throughout the test. During the first hour, all the trays experienced rapid increase in temperature due to high energy input from both heating sources (solar and biomass) but began to decrease steadily afterwards. The ambient temperature variation followed a similar pattern as those of the trays. The hybrid heat source has an advantage over sole dependence on biomass or solar drying as the maximum drying temperature offered was up to $67^{\circ} \mathrm{C}$.

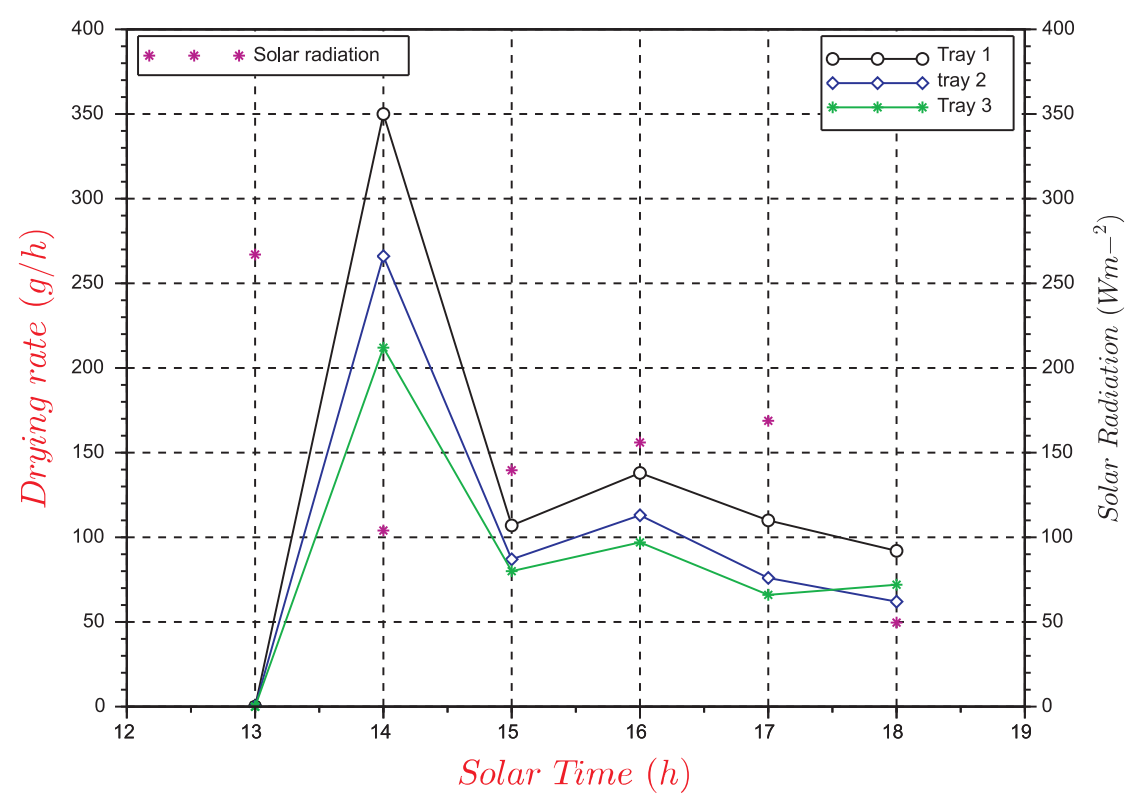

Figure 9b: Drying rate of cassava chips using Solar-biomass heating

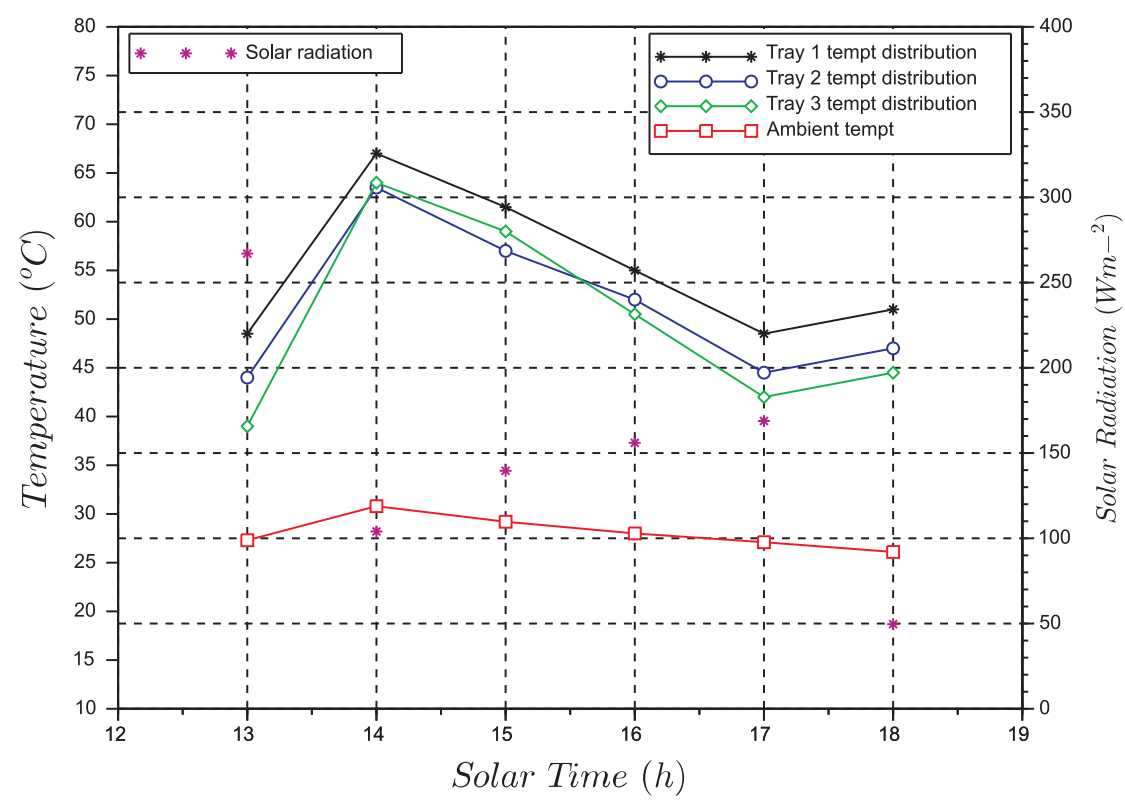

Figure 9c: Temperature distribution on trays using solar-biomass drying of cassava chips 


\subsection{Comparative performance with previous designs}

The results obtained in this work with solar drying agree well with that in Rathore et al. (2012) in terms of temperature distribution pattern in trays even though solar radiation was as high as $900 \mathrm{Wm}^{-2}$ in their work. If heat losses are minimized in this present work, drying efficiency would be increased to be comparable with that obtained in Rathore et al. (2012).

Table 2 compares the previous result obtained from the initial design (Okoroigwe et al., 2013) with the result obtained in the present work which shows improvement over the previous work. Using equations $4-6$, the dryer efficiencies were calculated as $16.04 \%, 3.34 \%$ and $8.96 \%$ for solar, biomass and solar-biomass heating respectively. According to Madhlopa and Ngwalo (2007) and Brenndorfer et al. (1985) they reported efficiency of $10-15 \%$ for natural convective solar dryers while Bena and Fuller (2002) reported drying efficiency of 22,6 and $8.6 \%$ for a direct type free convective solar dryer under solar, biomass and solar-biomass operating modes respectively. Comparing this work with the literature values above, it appears that the design used in this study performed consistent to the reported values. Lokeswaran and Eswaramoorthy, (2013) reported a dryer efficiency of $19 \%$ and showed that better and quicker drying takes place under combined mode of drying than when depending on only solar or biomass drying but Leon and Kumar, (2008) showed that drying time can be reduced by $66 \%$ in solar and biomass combined dryers in comparison with open sun drying. As no two solar dryers operating under different meteorological conditions will perform in the same way, the numerous advantages of solar based dryers such as prevention of contaminants, tedious loading and unloading in open air during bad weather and consistent drying, make them more attractive than open sun drying. The use of inte- grated system of drying, like solar-biomass hybrid dryers of this nature, would help to minimize the drying time, deterioration of the final product quality and energy consumption in drying which accounts for up to $15 \%$ of all industrial energy usage (Hossain et al., 2008; Bala et al., 2010; Kowalski and Mierzwa 2011). The versatility of solar hybrid dryers makes them flexible to adopt, that is, the same design of a solar dryer can be used for diverse crops (Farkas, 2013).

\section{Conclusion}

A solar-biomass hybrid dryer was improved upon and its performance evaluated under three heating modes using 3 food samples. The efficiency of the solar collector is $61.42 \%$ with average exit temperature of $38.02^{\circ} \mathrm{C}$. The average maximum tray temperature of $49^{\circ} \mathrm{C}$ was recorded on no load test with solar heating only, while the average maximum temperature of $65^{\circ} \mathrm{C}$ was recorded in a similar test with biomass heating only. When drying groundnut using biomass, only $53^{\circ} \mathrm{C}$ was the maximum tray temperature while $46^{\circ} \mathrm{C}$ was recorded when drying okra with solar heating only. The maximum tray temperature of $67^{\circ} \mathrm{C}$ was obtained on hybrid mode in tray 1 . The efficiency of the dryer based on solar, biomass and solar-biomass heating when drying fresh okra, fresh groundnut and fresh cassava chips increased from $5.19-16.04 \%, 0.23-3.34 \%$ and $1.636-8.96 \%$ respectively over the initial prototype design. The results obtained show that further improvement will enhance the efficiencies of the dryer on solar, biomass and hybrid mode. Further work on this dryer would focus on exergy and energy analyses with a view to determine the most vulnerable thermal loss points in the system. In addition, the effect of drying temperature on the nutritional values of the dried food samples should be evaluated as further work.

Table 2: Comparative performance of the previous and present designs

\begin{tabular}{|c|c|c|c|c|c|c|}
\hline \multirow[t]{2}{*}{ Parameter } & \multicolumn{3}{|c|}{ Previous design } & \multicolumn{3}{|c|}{ Improved version } \\
\hline & Solar & Biomass & Solar-Biomass & Solar & Biomass & Solar-biomass \\
\hline Maximum tray temperature $\left({ }^{\circ} \mathrm{C}\right)$ & 49 & 38 & 53 & 46 & 53 & 67 \\
\hline Total initial mass of sample dried (g) & 360.00 & 260.20 & 360.0 & 2910.0 & 2010.0 & 5250.0 \\
\hline Final mass of dry sample (g) & 260.4 & 249.0 & 260.6 & 840 & 1462 & 3365 \\
\hline Drying duration (hr) & 5.00 & 1.25 & 2.5 & 20.0 & 7.0 & 5.0 \\
\hline Mass of charcoal used (kg) & - & 1 & 1 & - & 1.2 & 1.4 \\
\hline Initial moisture content of sample (\%) & 70 & 70 & 70 & 81.00 & 27.30 & 51.70 \\
\hline Final moisture content of sample (\%) & $58.50 *$ & $68.60^{*}$ & $58.56^{*}$ & 33.94 & 1.93 & 24.13 \\
\hline Average drying rate $(\mathrm{g} / \mathrm{h})$ & $6.672 *$ & $2.952^{*}$ & $13.272 *$ & 28.75 & 22.83 & 107.11 \\
\hline Mass of water removed $(\mathrm{kg})$ & $0.0996^{*}$ & $0.0112^{*}$ & $0.0994^{*}$ & 2.070 & 0.548 & 1.885 \\
\hline Drying efficiency (\%) & $5.19 *$ & $0.23 *$ & $1.64 *$ & 16.04 & 3.34 & 8.96 \\
\hline
\end{tabular}


$A_{c}=$ Area of the collector

$C_{p}=$ the specific heat capacity of air at the mean temperature,

$\mathrm{H}_{\mathrm{f}}=$ heating value of the fuel (charcoal),

$\mathrm{H}_{\mathrm{t}}=$ Solar radiation

$\mathrm{L}_{\mathrm{v}}=$ latent heat of vaporization of water

$M_{i}=$ initial mass of the sample $(\mathrm{g})$

$M_{c}=$ Moisture content

$\mathrm{M}_{\mathrm{d}}=$ mass of dry matter

$\mathrm{M}_{\mathrm{w}}=$ mass of water removed,

$m_{f}=$ mass of fuel (charcoal) burnt

$\mathrm{m}_{\mathrm{a}}=$ mass flow rate of air $=$ density of air $\mathrm{x}$ wind speed $\mathrm{x}$ air duct area

$\mathrm{Q}=$ solar heat gain through the wall and the roof of the drying chamber

$R_{d}=$ drying rate

$\eta=$ efficiency

\section{References}

Agrawal A; and Sarviya, R. M (2014). A review of research and development work on solar dryers with heat storage. Int. J. Sustainable Energy doi:10.1080/14786451.2014.930464

Ajao K R; and Adedeji, A. A. (2008). Assessing the drying rates of some crops in solar dryer (case study: vegetables, tuber and grain crops). J. Res. Info. Civil Eng., 5(1), 1 - 12.

Bala B K; Hoque M A; Hossain, M A; and Uddin. M.B. (2010). Drying characteristics of asparagus roots (Asparagus racemosus wild), Drying Tech.: An International Journal 28(4), 533 - 541. doi: 10.1080/07373931003618899.

Barki, E; Ibrahim, J.S; and Eloka-Eboka A.C. (2012). Performance evaluation of an efficient solar dryer with a backup incinerator for grated Cassava under Makurdi humid climate. International Journal of Environment and Bioenergy, 1(2):131-139.

Bena B.; and Fuller, R J. (2002). Natural convention solar dryer with biomass backup heater. Sol. Enrgy. 72, $75-83$.

Brenndorfer, B; Kennedy, I; Baterman, C O; Trim, D S; Mrema, G C; and Wereko-Brobby, C. (1985). Solar dryers - their role in post-harvest processing. C'wealth. Sci Council, Marlborough, Pall Mall, London SW1Y 5HX.

Chavan, B.R; Yakupitiyage, A.; and Kumar, S. (2008). Mathematical modelling of drying characteristics of Indian mackerel (rastrilliger kangurta) in solar-biomass hybrid cabinet dryer. Drying Tech.: An International Journal, 26(12), 1552 - 1562. doi:10.1080/07373930802466872.

Dincer, M. M; Hussain Sahin, A. Z; and Yilbas, B. S. (2002). Development of a new moisture transfer (Bi-Re) correlation for food drying applications. International Journal of Heat and Mass Transfer, 45, 1749-1755

Dovic, D; and Andrassy, M (2012). Numerically assisted analysis of flat and corrugated plate solar collectors thermal performances. Solar Energy 86, 2416-243.

Farkas, I. (2013). Integrated use of solar energy for crop drying. Drying Tech.: An International Journal 31(8), 866 - 871 doi: 10.1080/07373937.2013.790410. 
Fudholi, A; Sopian, K; Bakhtyar, B; Gabbasa, M; Othman, M.Y; and Ruslan, M.H. (2015). Review of solar drying systems with air based solar collectors in Malaysia. Renewable and Sustainable Energy Reviews 51, 1191-1204.

Fudholi, A; Sopian, K; Ruslan, M.H; Alghoul, M.A; and Sulaiman, M.Y. (2010). Review of solar dryers for agricultural and marine products. Renewable and Sustainable Energy Reviews 14, 1-30.

Hashemi, S J; Roald, M; and Murray, D W J (2003). Mechanism of through air drying of paper: application in hybrid drying. Drying Tech.: An International Journal 21(2), 349 - 368. doi: 10.1081/DRT120017755.

Hossain M A; Amer B. M.A.; and Gottschalk, K. (2008) Hybrid solar dryer for quality dried tomato. Drying Tech.: An International Journal 26, (12), 1591 1601. doi:10.1080/07373930802467466.

Ibrahim, J. S.; Eloka-Eboka, A. C.; and Barki. E. (2014). Comparative Analysis and Performance of Solar Dryers with Backup Incinerators for Nsukka Sub-tropical and Makurdi Humid Locations Using Selected Farm Produce. British Journal of Applied Science \& Technology 4(3): 525-539,

Khalifa, A. J. N.; Al-Dabagh, A.M.; and Al-Mehemdi. W. M. (2012). An Experimental Study of Vegetable Solar Drying Systems with and without Auxiliary Heat. ISRN Renewable Energy, 2012, Article ID 789324, 8 pages. http://dx.doi.org/10.5402/2012/789324

Kiremire, B. T.; Musinguzi, E.; Kikafunda, J. K.; and Lukwago, F. B. (2010). Effect of Vegetable Drying Techniques on Nutrient Content- A Case Study of South- Western Uganda. African Journal of Food, Agriculture, Nutrition and Development. Vol. 10 No. 5.

Kordylas, J. M. (1990). Processing and Preservation of Tropical and Subtropical Foods. Macmillan Publishers Ltd., London U. K.

Kowalski S J; and Mierzwa, D (2011). Hybrid drying of red bell pepper: energy and quality issues, Drying Tech.: An International Journal 29 (10), 1195 1203. doi: 10.1080/07373937.2011.578231.

Lalit, M; Bal, S. S.; and Naik, S.N. (2010). Solar dryer with thermal energy storage systems for drying agricultural food products: A review. Renewable and Sustainable Energy Reviews 14, 2298-2314.

Leon, M A; and Kumar, S: (2008). Design and performance evaluation of a solar-assisted biomass drying system with thermal storage. Drying Tech.: An International Journal 26, (7), 936 - 947 doi: 10.1080/07373930802142812

Leon, M A; Kumar, S; and Bhattacharya, S. C. (2002). A comprehensive procedure for performance evaluation of solar food dryers. Renewable and Sustainable Energy Review 6, 367 - 393.

Lokeswaran, S; and Eswaramoorthy, M. (2013). Experimental studies on a solar drier system with a biomass back-up heater. Enrgy Sources, Part A: Recovery, Utilization, and Environmental Effects. 35(5), $467-475$ doi:10.1080/15567036.2010.511434.

Madhlopa, A; and Ngwalo, G (2007). Solar dryer ther- mal storage and biomass-back up heater. Solar Energy. 81, 449 - 462.

Naidu M. M; Vedashree, M; Satapathy, P; Khanum, H; Ramsamy, R; and Hebbar. H. U. (2016). Effect of drying methods on the quality characteristics of dill (Anethum graveolens) greens. Food Chemistry 192, 849-856.

Okoroigwe E C., Eke M N., and Ugwu H U (2013). Design and evaluation of combined solar and biomass dryer for small and medium enterprises for developing countries. Int. J. Physical Sci. 8(25), 1341-1349.

Onayemi, O. (1981). Post-Harvest Food Loss Management in Nigeria. Industry and Environment 4:5-8.

Phadke, P. C; Walke, P. V; and Kriplan, V. M. (2015). A review on indirect solar dryers. ARPN Journal of Engineering and Applied Sciences, 10(8), 33603371.

Prakash, O; and Kumar, A. (2014). Solar greenhouse drying: A review. Renewable and Sustainable Energy Reviews 29, 905-910.

Prasad J.; Prasad, A; Vijay, V K. (2006). Studies on the drying characteristics of Zingiber officinale under open sun and solar biomass (hybrid) drying. International J. Green Energy, 3 (1) 79 - 89 doi: 101080/01971520500439526.

Prasad, J.V; Vijay, V; Tiwari, G; and Sorayan, V (2006). Study on performance evaluation of hybrid dryer for turmeric (curcuma longa l) drying at village scale. J. Food Eng. 75, 497 - 502.

Rathore, N S.; Panwar, N L; and Asnani, B (2012). Performance evaluation of solar tunnel dryer for grape drying. International J. Ren. Energy Tech. 3(1), 1-10.

Ratti, C; and Mujumdar, A. S. (1997). Solar dryer of foods: modelling and numerical simulation. Solar Energy, 60, 151-157.

Smitabhindu, R; Janjai, S; and Chankong, V. (2008). Optimization of a solar-assisted drying system for drying bananas. Renewable Energy; 33, 1523-31.

Yassen, T A., and Al-Kayiem, H. H. (2015). SolarBiomass Hybrid Dryer Enhanced by the Co-Gen Technique. Drying Technology: An International Journal. DOI: 10.1080/07373937.2015.1051662.

Yunus, Y M., Al-Kayiem, H. H., and Albaharin, K. A. K. (2011). Design of a biomass burner/gas-to-gas heat exchanger for thermal backup of a solar dryer. J. of Appl. Sci. 2 (2) 1929 - 1936 doi: 10.3923/jas.2011.1929.1936.

Received 15 April 2015; revised 3 November 2015 